\title{
Formation and development of education management in Ukraine: historical excursion (1917-2018)
}

\author{
O. O. Nazarenko \\ Hlukhiv National Pedagogical University of Alexander Dovzhenko, Hlukhiv, Sumy Region, Ukraine \\ Corresponding author. E-mail: nazarenko_sasha18@ukr.net
}

Paper received 24.04.19; Accepted for publication 08.05.19.

\begin{abstract}
https://doi.org/10.31174/SEND-PP2019-197VII79-11
\end{abstract}
\begin{abstract}
The article deals with the historical formation of the education management in Ukraine in the period from 1917 to 2018. We have found that the modernization of the professional training of education managers is connected with the need of the society to have highly qualified specialists who are capable of: mastering the knowledge in the theory of management; realize the goals of reforming education; creatively comprehend the purpose and tasks of the functioning of institutions and educational institutions and their management, the prospects for their development, the essence of innovative theories, ideas, modern technologies.
\end{abstract}

Keywords: manager of education, school, director, head, educational institution.

Introduction. The modernization of the education system in Ukraine is directly related to the improvement of its managerial component. At the beginning of the twentieth century, management began to be regarded as an independent sphere of activity that can bring success to the organization. Thus, the beginning of a fundamentally new stage in management - the scientific management, the central figure of which became a professionally trained manager.

Analysis of recent researches and publications. Research on the problems of the historical development of the field of management in education and the formation of the profession of the heads of educational institutions are found in scientific works: S.V. Mayboroda (management of educational institutions of Ukraine (20th - 30th years of the twentieth century), O.I. Marmazi (formation and development of management in the field of education), VS Pikelnaya (the origin of science in education management and its development), L.V. Vasilchenko, I.V. Grishina, (historiography of the problem of forming the professional competence of school heads), V.S. Bereki (historical and pedagogical analysis of the problem of professional training of masters in education management). Theoretical and methodological aspects of modern professional training of educational managers establishments in Ukraine are highlighted ena in the writings of researchers L.V. Vasilchenko, V.V. Kryzhko, V.S. Pikelnaya, Y.M. Khrykova, V.D. Fedorova and others. Formation of professional competence of school principals is considered in the works: T.B. Volobuyeva (self-education activity of the head), G.V. Jelnikova, R.P. Vdovichenko (managerial competence of the school head), O.I. Marmazi (management in education: secrets of successful management), L.I. Danilenko (preparation of the head of the secondary educational institution), L.S. Tokaruq (preparation of the heads of boarding schools), G.M. Timoshenko (system of reserve preparation for heads of comprehensive educational institutions), T.M. Sorochan (methodical recommendations for the development of the professionalism of managerial activity of heads of general educational institutions in the system of postgraduate pedagogical education), V.K. Melnyk (improvement of managerial qualification of heads of comprehensive educational institutions in the system of post-graduate pedagogical education), I.A. Senchi (pedagogical conditions for the formation of a research culture of future managers in the process of pro- fessional training), N.V. Vasylenko (preparation of the head of the general educational institutions for innovation), S.V. Burdin (Masters in Management of Education in US Higher Educational Institutions), S.V. Byborodova (preparation of education leaders in the UK), L.V. Voznyuk (development of managerial culture of the head of the institution of secondary education), O.M. Captain (development of professional and pedagogical creativity in future managers), VS Berek (theoretical and methodological basis of education managers training).

The purpose of the article is to study the process of formation of professional training of education managers in Ukraine in the period 1917-2018 of the twentieth century.

Research findings and discussion. On the basis of a retrospective analysis of the formation and development of the professionalization of the managers of educational institutions, the dynamics of changes in approaches to the management of educational institutions has been traced. In the period from 1917 to 2018 , the nature and characteristics of management of educational institutions are reflected in the sequence of social determinants.

Here are the characteristics of the main stages: the first stage - from 1917 to 1930 - is characterized by the lack of professional training of education managers. In 19171919, authority in Ukraine changed several times, and each government solved the issue of developing Ukrainian education in its own way. The Revolution of 1917 abolished the old inspection of public education and transferred the management of local education to local governments, which was then reformed on a democratic basis [29, p. 780]. In June 1917, the Universal of the Central Council proclaimed the autonomy of Ukraine and established the first structural unit to manage the education system of the General Secretariat of Education. His activities were headed by I.Steşhenko. The Central Rada has developed the structure of the management of education, restored the activity of the All-Ukrainian Teachers' Union. One of the employees of the preschool education department was S. Rusova at that time. An important figure in this period is also O. Barvinsky, who, after the formation of the ZUNR in 1918, was secretary of education and religion in the first State Secretariat.

Hetman P. Skoropadsky's government formed the Ministry of Education headed by M. Vasilenko. Primary issues in the organization of the education system were: 
centralization of education; abolishing education departments for national minorities; abolition of school councils in the regions of Ukraine. The renewal of the Ukrainian People's Republic has preserved the Ministry of Education as the main administrative unit. It was headed by $\mathrm{I}$. Ogienko, who returned decentralization processes to the education system of Ukraine [18, p. 143-145; 21, p. 123125]. From the first half of the twentieth century the activity of Y. Chepiga is also associated with S. Cherkasenko, O. Mizychenko, S. Rusova, who leads the movement for the creation of a national school. Among his articles devoted to the most painful issues of schooling in Ukraine, there are work related to the organization of the education system [21, p. 180]. In the "Regulations on a single labor school (1918)" it was determined that the school head is elected by its team of teachers of the school. The head was the executive officer of the team, and the supreme body of school self-government was the school council. This was a manifestation of a democratic approach, but the activities of the head of the school had certain limitations that hampered the development of its functional effectiveness, deprived independence in solving important problems and making decisions, which often led to spontaneity in school management [8]. During this period, the scientific works of Professor M. Iordansky "School of Management" (1918) and the monograph " School science", which examined and considered the issues of the theory and techniques of management of a comprehensive school. With the strengthening of state structures at the same time there is a departure from democratic positions. So, in the "Statute of the only labor school (1923)" in the section "School Management" in relation to the rights and responsibilities of managers for the first time was determined the functional status of the head of the educational institution. It was assumed that the head of the school has the right to cancel the decisions of the Council of the school, and in some cases make independent decisions without the Council of School [9]. Consequently, this stage is characterized by an authoritarian-functional approach to the management of educational institutions.

For the second stage - from the 30's to 40's of the twentieth century. - the decisive is the totalitarianization of power. M. Iordansky, a major contributor to the development of the theory of education management in the USSR of the 1920's - 1930's, focuses on issues of school science. He considered school education as an integrated discipline, which studies the fundamentals of the organization of school affairs and the interconnected parties of the internal life of the school (management of the school in the administrative-economic and pedagogical terms, the material base of the school, the organization of the educational process, the status of teachers and students, school self-government ) M. Iordansky substantiated the ways and means of implementing mass popular education, advocated the creation of a public-public school management system, the broad involvement of the population in participation in school life, etc. [28]. In 1932 M. Iordansky in his works for the first time in the domestic pedagogy uses the term "management". He not only substantiates the specific organization of school life, but also makes an attempt to build a scholarly school curriculum as a discipline [33]. Some influence on the develop- ment of the experimental component of the theory of pedagogical management in the USSR was published in 1927 by the work of the German scientist V. Laia "Experimental Pedagogy" [17]. An important role in this period is played by M. Veselov and D. Loginov. At the same time, for this period, the intensive intervention in the management of the school of party organizations is being characterized with the aim of communist ideologization. In the middle of the 1930s, it became clear that there was a need to strengthen the managerial system in the education system. At that time, requirements were created for the director of the school as a representative of the state and at the same time a qualified teacher. At the same time, in the conditions of the administrative-command system, the control functions are given preference. A characteristic feature of prewar time is the emergence of textbooks on pedagogy sections "School science" In 1939 the book was published by B. Yesipov and other authors, one of the sections entitled "Management and management of the school". This section addresses the principles of school management and guidance. However, there is no clear boundary between these terms.

In 1939 it also comes from the publication "Pedagogics" edited by I. Kayrov, which has a separate chapter "School Management", which has a typical structure for that time. Attention is mainly given to the planning of work and the current leadership of the school. At the same time, a special unit is dedicated to highlighting the work of the school principal and his educational assistant [28, p. 495-511]. In 1940 Pedagogics was published, edited by P.Grudzhev, part of which was devoted to school studies, built on the same principle [26, p. 578-619]. The views of the leaders of the field of education during this period were significantly influenced by A. Makarenko's works, in which he covered his pedagogical system for organizing the activities of the pedagogical and student groups of the school. It is well-known that A. Makarenko had a great practical management experience.

By the decree "On the structure of elementary and secondary school" in 1934, the post of the head of the school was renamed the director. At that time, the lack of vocational education of school principals was offset by an increase in their qualifications through short-term courses, meetings, conferences. An important factor determining the person's readiness to serve as a leader was ideological and political commitment to the ideals of the communist party. Consequently, this stage is characterized by an administrative-supervisory approach, as state control over educational institutions is intensifying.

The third stage covers the 40's - 60's of the twentieth century and is characterized by a lack of targeted professional training of school administrators. School studies as a branch of pedagogical science, whose purpose is to study the content and methods of school management, the disclosure of the features of the school management system, the organization of its work, becomes a recognized part of pedagogy in its modern sense [34, p. 404]. The terms "management" in that period are considered synonyms, the clear division between them is absent. Among the fundamental works of that period, the "School science" edited by O. Volkovsky and M. Malyshev, which came out in 1955, O. Volkovsky and others, highlighting the methodological foundations of Soviet school educa- 
tion, emphasized that "the management and guidance of institutions of the system of people education is a direct and direct expression of the policy of the Soviet state. "

The authors consider the issues of education management from the level of the school to the level of the Ministry of Education. The structure of the corresponding annual plans of the education management bodies is provided. Among the functions of control is the control function.

In the work considerable attention is paid to the activities of the school principal, carefully written out the implementation of his main managerial functions, with emphasis on the implementation of control functions [36, p. 5-7, p. 113-120]. During this period, the work of the outstanding teacher V. Sukhomlynsky, who in 1955 defended his Ph.D. thesis "Director of the School - Head of Educational Work" at the Taras Shevchenko University of Kyiv. Among his works, which significantly influenced the views of the leaders of the domestic education system, should be called the book "Conversation with the young director of the school" [32]. On the peculiarities of the management of the educational system during this period was influenced by the law of the USSR "On strengthening the connection of school with life and on the further development of the education system in the USSR" of December 24, 1958, which introduced compulsory eightyear education. Adoption of the law was the result of a certain democratization of all spheres of life during the "Khrushchev thaw". Accordingly, in the Ukrainian SSR the Law "On strengthening the connection of the school with life and the further development of the system of public education in the Ukrainian SSR" was adopted (April 17, 1959) [12; 18].

During this period, the activities of management of educational institutions are declared as democratic, but in fact it is strictly regulated by the authorities and party leadership. In the Law "On Strengthening the Relationship Between School and Life and Further Development of the National Education System in the USSR", adopted in 1958 , it was determined that the director manages the school, optimally combining unity and collegiality, based on the activities of the pedagogical council, party and trade union organizations, involves the help of the school of parents of students, chef enterprises [5]. Thus, the third stage is characterized by an authoritarian-system approach.

The fourth stage - the 60's - 80's - is marked by the system-complex approach to the improvement of the qualifications of the managers of educational institutions. It is at this time that the main social and role functions of the head of the school are distinguished - the management and implementation of an integrated approach to the education and training of students, scientific management of the educational process, work with the public and parents of students, active influence on educational processes in the city, socio-political, administrative -pedagogical, economic activity and educational and educational work. The level of professional competence was perceived as a certain degree of formation of professional knowledge, skills and some qualities of personality, which are necessary for work and implemented in it [3]. Scientific developments on problems of the activity and competence of education managers (E.S. Berezniak [3], R. Kh. Shakurov
[3] and other authors). On November 10, 1966, the Central Committee of the CPSU and the Council of Ministers of the USSR adopted Resolution No. 874 "On Measures for the Further Improvement of the Work of a Secondary School", which identified the most important task in the field of public education - the implementation, mainly until 1970, of compulsory secondary education for the young person generation [18, p. 167-168; 23, p. 93-97]. All this stimulated the professional growth of teaching and management personnel.

The answer to the demands of the time was the article M. Sotserdotov and M. Cherpinsky "School Science, his subject and tasks" (1969), which had a methodological character and significantly influenced the development of the theory of education management in the specified period [30]. During this period, the work of J. Wisgard and other authors of the "School of Pedagogy" is also published, in which a separate section is devoted to issues of school education.

A direct unit of the school is devoted directly to the school, which deals with the unity and teamwork in the work of the school, planning and organizing methodological work.

In the 1970s and 1980s, the bar of claims to the heads of the education sector rose again after the adoption of the resolution of the Central Committee of the CPSU and the Council of Ministers of the USSR of June 20, 1972, No. 463 "On completing the transition to universal secondary education of young people and the further development of a comprehensive school", which before bodies the people's education put forward the task of completing the implementation of secondary education, the transition to new curricula and programs [18, p. 168; 23, p. 98-100]. On November 28, 1973, the order of the Ministry of Education of the USSR No. 266 "On Improving In-Service Leadership and Control in Secondary Schools of the Ukrainian SSR" was issued. It was one of the key documents of the time, which drew attention to the need for scientific management of the school.

Significant contribution to the development of the theory of management of the educational process at school belongs to Yu. Babansky and his theory of optimization of the educational process in school. The first work of the author dates back to the mid-1950s, but the most active activity dates back to the 1970s-1980s. During this period, a number of works devoted to the problems of managing educational work and optimizing the organization of the educational process in school $[1 ; 2]$. In the 1970s, certain changes were made in the views on the theory of educational management in the developed countries of the world.

Thus, the fourth stage is characterized by a systemintegrated approach. Awareness of the importance of the level of professional competence, as a certain degree of the formation of professional knowledge, skills and some qualities of the individual, led to the creation of the first scientifically grounded educational and thematic plans for the improvement of the skills of school principals.

The fifth stage - from the 80's to the 90's - marks the beginning of an active research by the researchers of the classifications of personal professional qualities of the director of a secondary school and their influence on the functioning of the institution. School directors of these 
years have chosen the staff of the educational institution. In the 1980s and 1990s, a significant number of works on a functional approach to education management appeared. In this period, the concept-terminology apparatus of school science is actively being developed. School management, as part of the development of a systematic approach, begins to be actively considered as a complex social and educational system. For the first time, a thoroughly systematic approach to school management was highlighted by Y. Konarzhevsky, one of the leading theories of education management at the end of the twentieth century. in the post-Soviet space. April 12, 1984, the Central Committee of the CPSU, the Council of Ministers of the USSR adopted Resolution No. 313 "On Further Improvement of the General Secondary Education of Youth and Improvement of the Working Conditions of the General School" Implementation of the school reform envisaged the improvement of the content of education, methods and means of education and education, further strengthening of the school's relations with life The high school was eleven years old. The main directions of secondary and vocational schools were approved by the decision of the Supreme Soviet of the USSR on April 12, 1984. A characteristic feature of this document was the presence of section VIII "Improving the management of public education" $[20$, p. $376 ; 23$, p. 9-25, 105-114]. This section, like the whole document, is more political than the administrative-applied character.

Considerable attention is being paid to the training of senior school staff, which creates special centers for preparing the reserve for general school leaders, and so on. Particular attention is paid to the district administration of education [22, p. 133-138]. However, the main thing in the training of heads of educational institutions remains the ideological component, and not the perfect mastery of the fundamentals of the theory of management. At the higher level of management education begins to focus on the effectiveness of improving general secondary education, but this efficiency is proposed to be considered from the class positions in accordance with the political and ideological goals [22, p. 150]. The proof of this is the work of L. Kolesnikova and other authors "Efficiency of Education" (1991). On the one hand, this is a certain step forward, but on the other - the bases of knowledge on general pedagogy with the ideological postulates of the CPSU and the basics of the political economy of socialism are mixed in the work [15]. It should be noted that the issue of school management during this period in textbooks on pedagogy is given little attention. So, in the course of lectures on pedagogy $\mathrm{T}$. Ilyina, which were published in 1984 and numbered about 500 pages, the section "School of Medicine" was allocated 21 pages, many of which were not related to the theory of education management and covered the ideological specificity [11 ] During this period, on the initiative of the Ministry of Education of the USSR, the series "Library of the Director of the School" begins, which is mainly applied in nature [31]. For the second half of the 1980s and early 1990 s, the publication of works focused on the head of the school is typical. This is the work of M. Portnov's "ABC of School Management" (1991) [27]. During this period, the solid work of our compatriots comes through: E. Berezniak's "Modern School Leadership" (1983), V.
Bondar "Management Activities of the School's Director" (1987) and B. Kobzar "School Management of the Extended Day" (1988 .) [5; 14]. However, all these works are not complex and cover some aspects of the system approach, the issue of school planning, the organization and control of the educational process.

Consequently, this stage is characterized by an authoritarian-competent approach, they begin to impose requirements for the competence of the head of the educational institution, as the renovation and development of the school is impossible without a high level of professionalism of its head. Traditional management of educational institutions was focused on the implementation of instructions (instructions, recommendations, orders) of senior management bodies. The director of the school received instructions, tasks from the authorities that had to be carried out.

During the sixth stage - from the 90s till the 2000th the professional training of the managers of educational institutions was started. This stage covers the collapse of the USSR and the formation of an independent Ukrainian state, a gradual departure from the authoritarian style of governance in various fields and in education in general. The issue of granting a professional status to the head of an educational institution is getting worse. There is a need to teach the head of the school to manage the development of the school, direct the research and search activities of teachers and students. Along with the notion of "manager" began to widely use the term "manager". The management of education is developing, the issue of granting a professional status to the school head is exacerbated. The existing system for the improvement of the qualifications of the heads of educational institutions could not solve the problems of conceptuality, management professionalism $[13,28]$. The requirements for the qualification of heads of educational institutions are improved in the case of assigning them qualification categories, which include the following indicators: qualification; professionalism; performance activity. An analysis of them testifies to the orientation towards the formation of the operational sphere, with a clear underestimation of the needs-motivational and reflexivity-evaluating spheres of their activity [16, 35-38]. In this period published G.A. Dmitrenko [9], N.L. Kolominskii [16], in which the essence of educational management is revealed, work related to the understanding of the need for the training of professional managers - education managers $[33 ; 47 ; 10$, 8]. There is a development of the national education system; the legislative and normative base of the step-by-step system of training specialists is formed; state standards of quality of education are developed; structural reorganization of higher educational institutions, magistrates [4, 92]. So, for the sixth stage, a management-adaptive approach is typical. The general use of the term "manager of education".

The seventh stage - from 2000 to 2009 - is characterized by the development of a system of professional training of leading educational staff - an innovative-reflexive approach.

There are first attempts of higher educational institutions to prepare a new generation of managers of educational institutions. Since 2000, the Ministry of Education and Science of Ukraine has developed the educational 
qualification of the Master in specialty 8.000009 - "Management of educational institutions", which corresponds to the State Standard of Higher Education and is part of its branch component. At this stage, the professional training of masters in this specialty began in higher educational institutions of Ukraine [13; 4]. Masters' professional training programs specializing in "Management of Educational Institutions" are being developed and improved, teaching aids, methodical recommendations, etc. are issued. Professional training of school administrators has become a full-fledged component of Ukraine's continuing vocational education system since 2000. For the preparation of masters in the new specialty and the improvement of the qualifications of the heads of educational institutions, appropriate programs and curricula have been developed. The higher education institutions of the IV level of accreditation of different types and forms of ownership and institutes of postgraduate pedagogical education are engaged in the professional training of masters in the specialty "Managers of educational institutions" in Ukraine. The system of higher and postgraduate education in Ukraine undergoes significant changes, which are defined in the general context of European integration. Of particular importance is the process of implementing European norms and standards, which requires a clear differentiation of requirements for updating the content of education and training of specialists of various educational qualification levels, certain forms of training and control, educational innovations [4, 383]. V.E. Berek notes that in the polyphony of pedagogical innovations the changes in the activity of higher educational establishments, their ability to respond situatively to the requests of practitioners and, at the same time, to maintain their mission to increase professional training, and the formation of professional competence of a specialist, are of particular importance. This involves a reorientation of the forms and methods of organizing training that would meet the peculiarities of the current socio-cultural situation and the task of updating the system of vocational education [8, 7]. We agree with the opinion of G.V. Kashkaryov [13] states that the modern manager must be significantly different from the traditional leader. This is due to new conceptual and technological approaches to activities, namely, humanization and democratization, human centered outlook, results management, programmatic, targeted and personally oriented management approaches, and other managerial innovations [35]. Scientist L.I. Danilenko [8] states that despite the emergence of topical works on planning of competence development and the training of leading pedagogical staff, a number of important aspects, in particular, the problem of selection and systematization of scientifically determined content, the definition of the rational structure and forms of integrated plans for the training and continuous improvement of the skills of education workers, do not have a sufficiently complete theoretical justification. The most important condition for implementing the main provisions of the concept is the development of theoretical issues and the preparation of a systematic approach to long-term plans for the continuous improvement of the skills of teaching staff, including school directors. Such plans are "system-complex", since they constitute a unified system as a subject of work with personnel at the state, oblast, and other levels, and in terms of content at each, complexly coordinated in general and differentiated at each level work with personnel taking into account specifics and possibilities of realization. There is a need to create system-complex programs and plans based on the selection of purposeful, meaningful, systematic information, which contains a set of methodological, normative, theoretical, subject-specific, methodological knowledge and practical skills necessary for the successful implementation by the manager of educational institutions of their official functions. How spontaneously claims L. E. Sigaeva, today the number of educational establishments has significantly changed, new types of different forms of ownership have appeared, and specialists are trained in new specialties that correspond to changes in the labor market. Such opportunities further expand the right of citizens to receive education through the possibility of choosing a form of education: full-time, evening, part-time, out-of-school, distance "[28, 164]. For Ukraine, with an extensive network of educational institutions of state and non-state forms of ownership, the management of the branch of education is characteristic, combining both elements of centralized and decentralized systems with the deployment of horizontal and vertical links between different levels and subjects of management, in this regard A positive role in improving the quality of management should be played, for example, by the planned measures for: expanding the decentralization factor, which creates better conditions for the democratization of governance, the development of creativity and the initiatives of the collection educational institutions; training of education managers; creation and development of open universities [28, 164]. In his work L.B. Lukyanova [19, 253] emphasizes that the transience of changes in modern society objectively predetermines the need to form a person capable of perceiving and creating changes that is designed to perceive these changes as natural norms. At the same time, the perception of the totality of changes is impossible without satisfying the educational needs of man throughout his life. Consequently, modern education should acquire an innovative content for changing educational needs, and subjects of the educational process - the ability of innovative lifestyles and learning. Analyzing the normative documents in the field of education management, we determine that based on the decision of the Board of the Ministry of Education and Science of Ukraine (Protocol No. 2/1-4 of February 23, 2006): "Increasing the efficiency of higher education is a determining factor in the growth of the socio-economic potential of the state" in paragraph 9 it is noted that the department of work with the personnel of higher education and civil service needs: 9.1. To develop the program "Head of a higher educational institution", foreseeing, in particular: the creation of standard requirements for the manager of higher education and the introduction of effective technologies for its training and professional development; creation of means for diagnosing the level of readiness of the head for effective management activity; developing a system for monitoring the activities of the manager at the university, regional, national and European levels; development of new approaches to formation of a reserve for a post of head of a higher educational establishment". L. B. Lukyanova emphasizes that the constant mastering of new 
knowledge, methods and technologies is an absolute factor in supporting the appropriate qualification of specialists, which substantiates the guiding principle of modern education - its continuity, which determines the strategic reference point for social progress [19, 253]. V.E. Berka highlights the principles of training future education managers: science, system and consistency, harmonization of learning process, integrity, motivation, activity of the individual, individualization of education, developing education, practical orientation; unity of consciousness and behavior; continuity and systematicity; the unity of the pedagogical requirements of the integrated approach; value-based approach; education in the team of positive motivation, positive imitation, practical orientation [9, 113]. The specific principles of the professional training of future managers of education include: the principles of integrity, continuity, integrability, interdisciplinarity, voluntariness and accessibility, variability; practical orientation; orientation on the development of the valuemotivational sphere of the individual; The expediency of combining the forms, methods and means of training and education, the content and objectives of the professional training of education managers [9, 113-114] The integral part of the pedagogical process (training) is the educational process in the university, which combines scientific, educational and methodological activities, work on selection, preparation and improvement of professional qualification of professors' staff, scientific work of students; creation, development and improvement of information and educational material and technical base. In the conditions of the master's degree in higher education institutions for the educational process, such forms of training as lectures, seminars, laboratory works, practical and group classes, colloquiums, business and role games, theoretical (scientific and practical) conferences, control works, computer testing, consultations, individual interviews, independent work of the masters, educational, managerial and pre-diploma practice, performance of graduation qualification (master's degree) work, etc. The main components of the educational process, which determine the direction of professional training of the Master in the specialty are the task, content, methods, techniques, means, forms of training, methods of stimulating learning activities and monitoring its effectiveness. Between the components of the educational process there are regular relationships. Taking into account social needs, the purpose of the educational process determines the specific tasks of learning, its content, which in turn determines the choice of methods, forms and means of learning [13, 33-34].

The eighth stage - from 2009 to 2018 - is characterized by the improvement of the training system of the education manager by updating the professional-managerial training of a future specialist.

Some of the global trends are inherent in the modernization of the content of education managers' training. Since 2009, the Ministry of Education and Science of Ukraine has developed a number of industry standards on the quality of training of management specialists (the direction standard of higher education in Ukraine, the educational-professional program of preparation for a bachelor's degree in the field of preparation 030601 "Management" of the field of knowledge 0306 "Management and administration" from 09.02.2009 Direction standard of higher education of Ukraine Educational and professional program of master's degree in the specialty 8.03060104 "Management of foreign economic activity" of the field of knowledge 0306 "Management and administration ents "from 22.04.2011 p .; higher education 073 specialty" Management "for the first (bachelor) level of higher education from 29.10.2018 year).

Such a decision was made because the training of management personnel for educational institutions requires filling the content of curricula not only with the disciplines of the psychological and pedagogical cycle, but a number of disciplines from various scientific fields, including the economic direction. Today, the head of the educational institution is a specialist who thoroughly Has management technology based on the use of modern management bases.

Starting from 2015, according to the Resolution of the Cabinet of Ministers of Ukraine dated April 29, 2015, No. 266 "On the peculiarities of the introduction of a list of branches of knowledge and specialties under which higher education students are trained", the training of the head of educational institutions is carried out in branch 07 "Management and administration" and specialty 073 "Management" (Management of educational institutions (by type). According to the decision of the Cabinet of Ministers of Ukraine "Procedure for preparing higher education graduates of the degree of doctor of philosophy and doctor of sciences in higher universities graduate institutions (scientific institutions) from 23.03.2016 the opportunity to obtain a doctor of philosophy and on specialty 073 "Management".

Conclusion. Thus, the urgency of the modernization of the professional training of education managers is related to the need of the society to have highly qualified specialists (teachers, heads of educational institutions, scientific workers) who are able to: master knowledge of the theory of social systems management, philosophy of education, sociology and management psychology, pedagogy, foundations market economy, management, finance and law, marketing, computer literacy, state, native and foreign languages, etc .; realize the goals of reforming education; creatively comprehend the purpose and tasks of the functioning of institutions and educational institutions and their management, the prospects for their development, the essence of innovative theories, ideas, modern technologies. In the last years, the content and structure, forms, methods and means of teaching, education and management have substantially changed. Such radical reformation of education requires high-quality high-tech training of teaching staff throughout their lives, in particular, in the postgraduate period, when the subsystem of professional growth of pedagogical workers plays an important role: from a qualified teacher to the head of an institution or educational establishment, a scientific worker, a competent citizen of a modern society of continuous education. 


\section{ЛІТЕРАТУРА}

1. Babansky Yu. K. Selected Pedagogical Works. M. Pedagogics, 1989. $560 \mathrm{pp}$.

2. Babansky Yu.K. Optimization of the pedagogical process: (in answers and answers). 2nd ed., Pererab. and add. K. I'm glad. Shk., 1983. 287 pp.

3. Bereznyak E.S. Management of the School's work. - K. I'm glad. school, 1970. 262 pp.

4. Bereta V.E. Theoretical and methodological bases of professional training of masters in education management: diss. .. d. Ped. N. : special 13.00.04 «Theory and methods of professional education». Kyiv, 2008. - 450 p.

5. Bondar V.I. Management activity of the school principal: didactic aspect. K. I'm glad. Shk., 1987. 160 p.

6. Vizgard Ya. A. Pedagogics of the school: [manual]. Part II The theory of upbringing. School Studies. Perm, 1969. - 324 p.

7. Hopkins D. Evaluation for School Development. Lviv: Chronicles, 2003. $256 \mathrm{p}$.

8. Danilenko L.I. Modernization of the content, forms and methods of managerial activity of the director of a secondary school: monograph. K. Logos, 1998. 140 p.

9. Dmitrenko G.A. Strategic management: Targeted education management based on a qualitative approach: teaching. manual. K. IZMN, 1996. 140 p.

10. El'nikova G.V. Fundamentals of Adaptive Management (lectures). X.: Issued. gr. "Basis", 2004. 128 p.

11. Ilyina T. A. Pedagogics: The course of lectures. Study manual for students of ped. Institov. M. Enlightenment, 1984. 496 pp.

12. Institute of History of the National Academy of Sciences of Ukraine - 1959 [Electronic resource]. - Access mode: http://www.history.org.ua.

13. Kashkaryov G.V. Preparation of masters for management of an educational institution in the conditions of personally oriented education [Electronic resource]. 2007. Access mode: http://www.bdpu.org/scientific_published/pedagogics_4_200 $5 / 11$.

14. Kobzar B. S. Management of the School of Extended Day. K. I'm glad. Shk., 1988. 188 pp.

15. Kolesnikov, LF, Efficiency of Education. M. Pedagogics, 1991. 272 pp.

16. Kolominsky N.L. Conflicts and Psychological Training of Education Managers to Their Forecasting, Prevention and Resolution. Conflict in Society: Diagnosis and Prevention: Mat. III International sci. pract. Conf. Kiev. Chernivtsi, 1995. pp. 303-307.
17. Lay V.A. Experimental Pedagogy. Moscow stock magazine. Society. Leningrad. 1927. 122 p.

18. Levkovsky M.V. History of pedagogy: teaching method. manual. K. Center for students. lit-ry, 2008. 190 p.

19. Lukyanova L. B. Educational models of adult education. Kharkiv: Style-Publishing, 2008. P. 252-262.

20. Lyubar O. O. History of the Ukrainian School and Pedagogy: Teach. manual. K. Knowledge, 2006. 447 pp.

21. Mosyshenko V.A. History of pedagogics of Ukraine in persons: teaching. Manual. Sumy: VTD "University Book", 2005. $266 \mathrm{p}$.

22. Myasnikov VA General Education School at a New Stage. K. I'm glad. Shk., 1986. 168 p.

23. People's education in the USSR: a collection of normative acts. M. Yurid. Lit., 1987. 336 p.

24. Basic documents about the school / composition. E. S. Bereznyak. K. Soviet school, 1982. 399 p.

25. Pedagogics / ed. I. A. Kairova. M. Uchpedgiz, 1939. 514 pp.

26. Pedagogics / ed. P. N. Gruzdeva. M. Uchpedgiz, 1940. 624 pp.

27. Portnov M.L. ABC of School Management. M. Enlightenment, 1991. $191 \mathrm{pp}$.

28. Sigaeva Larisa. Modernization of adult education system in independent Ukraine. K. Khmelnitsky, 2008. P. 158-165.

29. Siropolko S. History of education in Ukraine. K. Science thought, 2001. 912 p.

30. Sotserdotov N.I. School teaching, its subject and tasks. Soviet pedagogy, 1969. No. 9. P. 81-83.

31. Spector A. Y. Finances and economic activity of the school. M. Enlightenment, 1984. 208 p.

32. Sukhomlinsky V.O. Selected Works: 5 t. K. I'm glad. Shk., 1977. T. $4640 \mathrm{pp}$.

33. Management of an educational institution: teaching method. Manual. X. 2003. Ch. 1. 152 p.

34. Fitsula M. M. Pedagogics: Teach. manual for the stud higher ped shut up education K. Academy, 2000. 544 pp.

35. Shakurov R. Kh. Socio-psychological bases of management: the leader and pedagogical collective / M. Enlightenment, 1990. 208 p.

36. Schooling / ed. A. N. Volkovsky and M. P. Malysheva. M. State study.-Ped. from the Ministry of Education of the RSFSR. 1955. 518 p. 